\title{
Solar Energy Task Force Report Technical Training Guidelines
}
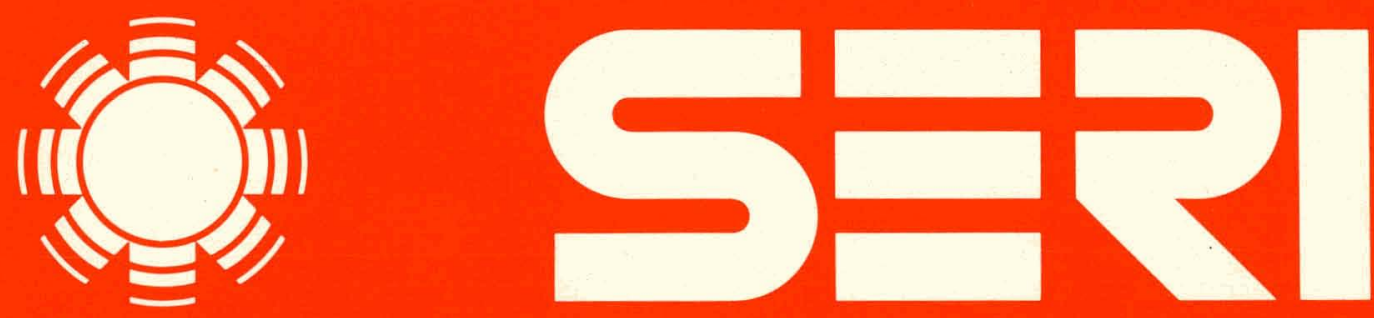

\section{Solar Energy Research Institute}

A Division of Midwest Research Institute

1617 Cole Boulevard

Golden, Colorado 80401

Operated for the

U.S. Department of Energy

under Contract No. EG-77-C-01-4042 


\section{DISCLAIMER}

This report was prepared as an account of work sponsored by an agency of the United States Government. Neither the United States Government nor any agency Thereof, nor any of their employees, makes any warranty, express or implied, or assumes any legal liability or responsibility for the accuracy, completeness, or usefulness of any information, apparatus, product, or process disclosed, or represents that its use would not infringe privately owned rights. Reference herein to any specific commercial product, process, or service by trade name, trademark, manufacturer, or otherwise does not necessarily constitute or imply its endorsement, recommendation, or favoring by the United States Government or any agency thereof. The views and opinions of authors expressed herein do not necessarily state or reflect those of the United States Government or any agency thereof. 


\section{DISCLAIMER}

Portions of this document may be illegible in electronic image products. Images are produced from the best available original document. 


\section{PREPARED UNDER TASK No. 4228}

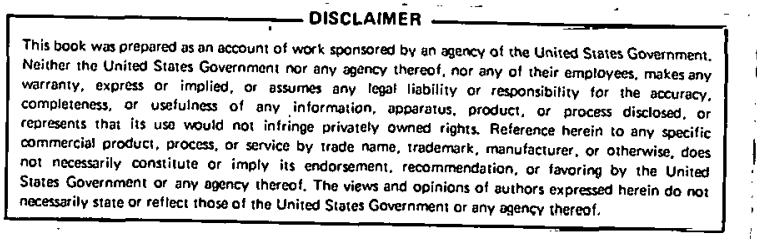

\section{Solar Energy Research Institute}

1536 Cole Boulevard

Golden, Colorado 80401

\section{A Division of Midwest Research Institute}

\section{Prepared for the}

U.S. Department of Energy

Contract No. EG $\cdot 77 \cdot \mathrm{C} \cdot 01 \cdot 4042$ 
THIS PAGE

\section{WAS INTENTIONALLY LEFT BLANK}




\section{FOREWORD}

The Solar Energy Task Force report summarizes information and discussions generated from the Task Force Workshop of 12-13 September 1978. The Task Force members, leaders in education, labor, and business involved with solar technical training programs, were assembled to study training problems. This report was formally presented at the National Energy Education, Labor, and Business Conference on "Energy-related Vocational and Technician Training, Employment, and Public Energy Awareness" held in Washington, D.C., 15-17 January 1979 under the sponsorship of the Department of Energy (DOE), Office of Education, Business, and Läbor Affairs.* The Solar Energy Task Force was stimulated by $D O E$, and coordinated and supported by the Solar Energy Research Institute (SERI).

The Task Force focused on solar space and water heating applications to provide guidelines for technical training courses and curriculum for vocational/technical schools and community/junior colleges. The report addresses questions of curriculum development; jobs, tasks, and skills that require training; and equipment recommendations for establishing a solar training center. The fundamental question of whether or not to offer a solar program is explored.

The contributions of the Solar Energy Task Force members are greatly appreciated. It is hoped that this will be a useful initial document for all those involved in solar technical training.

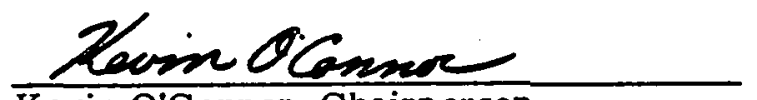

Kevin O'Connor, Chairperson

Solar Task Force

Approved for SERI:

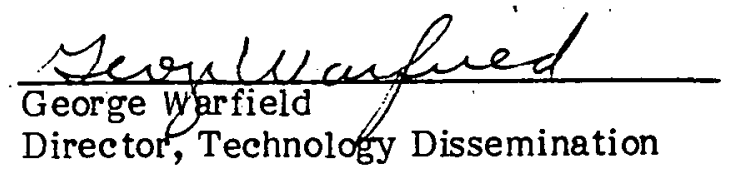

* The Task Force Report was originally distributed at the 15-17 January 1979 Conference in draft form only. The final, revised version is being produced so that nonconference attendees may benefit. This effort is in partial fulfillment of Task 4228-Vocational Training Programs. 
THIS PAGE

\section{WAS INTENTIONALLY LEFT BLANK}




\section{NOTICE}

This report was prepared for DOE by SERI and the Solar Energy Task Force members. Neither the United States, DOE, nor their employees; nor their contractors, subcontractors, or their employees; nor SERI, nor Task Force member makes any warranty, express or implied, or assumes any legal liability or responsibility for the accuracy, completeness, or usefulness of any information, apparatus, product, or process disclosed, or represents that its use would not infringe privately owned rights. Special mention of educational institutions, products, manufacturers, and reference materials is not meant to be an endorsement of such institutions, products, manufacturers, reference materials, etc. 
..

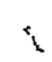

THIS PAGE

\title{
WAS INTENTIONALLY
}

\author{
LEFT BLANK
}


TABLE OF CONTENTS

Page

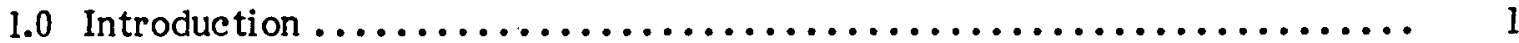

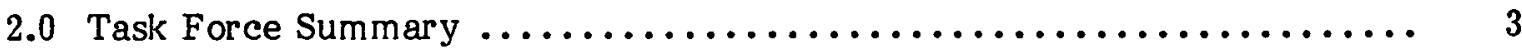

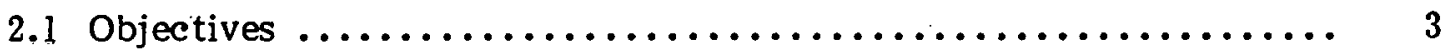

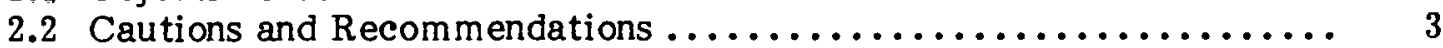

3.0 Solar Jobs and Associated Skills . . . . . . . . . . . . . . . . . 5

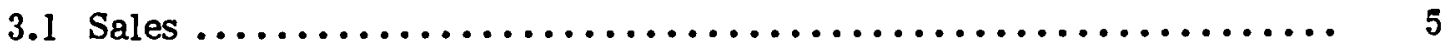

3.1.1 Describe Different Systems...................... 5

3.1.2 Show the Finished Product..................... 5

3.1.3 Explain Performance .......................... 5

3.1.4 Recommend a Particular System ................... 6

3.1.5 Explain System Operation and Maintenance ............. 6

3.1.6 Explain Impact on Comfort ..................... 6

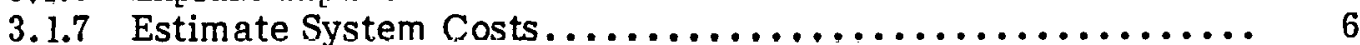

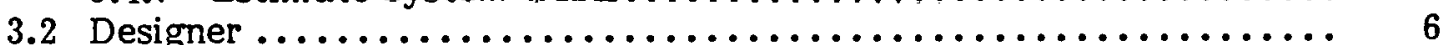

3.2.1 Select the Proper System ....................... 6

3.2.2 Select Optimum System Size................... 7

3.2.3 Calculate System Perf ormance................... 7

3.2.4 Provide Details on Operation .................... 7

3.2.5 Describe Installation and Maintenance $\ldots \ldots \ldots \ldots \ldots \ldots \ldots . \ldots \ldots$

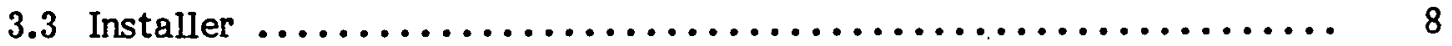

3.3.1 Install Collectors................................... 8

3.3.2 Make System Connections to Collectors ............... 8

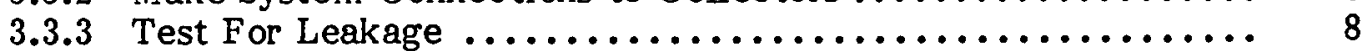

3.3.4 Locate, Construct, and Install Storage $\ldots \ldots \ldots \ldots \ldots \ldots \ldots . \ldots . \ldots . \ldots . \ldots . \ldots$

3.3.5 Connect Pipes and Ducts to Storage .................. 8

3.3.6 Install Collector/Storage Heat Exchangers, Pumps, Check Valves, Filters, and Isolation Valves............. 9

3.3.7 Connect the System with a Standard Backup

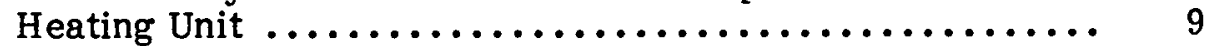

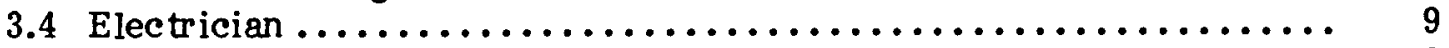

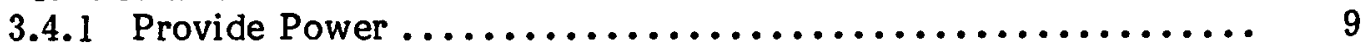

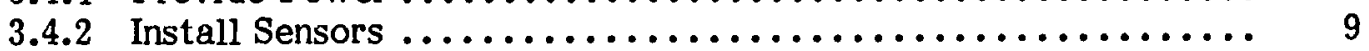

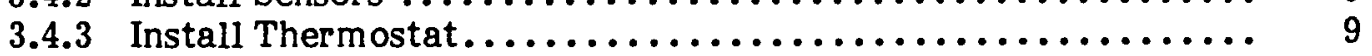

3.4.4 Connect Mechanical Device Controls to Controller ......... 9

3.4.5 Check Out Control Modes ........................... 9

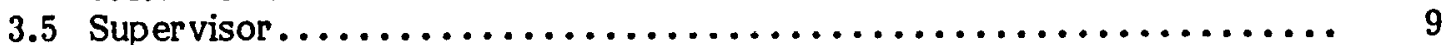

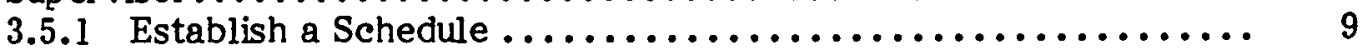

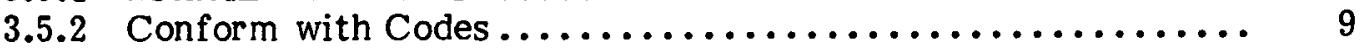

3.5.3 Conf orm Installation with Design ................. 10 
TABLE OF CONTENTS (concluded)

3.6 Service and Maintenance Technician .................... 10

3.6.1 Understand the General System Operation ............... 10

3.6.2 Identify the Control Mode of the System ................ 10

3.6.3 Determine If Mechanical Devices Are Operational ........... 10

3.6.4 Identify Points for Fluid Temperature Measurements........ 10

3.6.5 Determine If Heat Flows Are Nominal ............... 10

3.6.6 Locate Problems ............................. 10

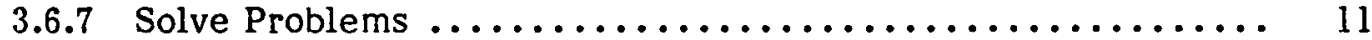

3.6.8 Execule Periudle Malntenance ...................... 11

3.6.9 Perform System Startup....................... 11

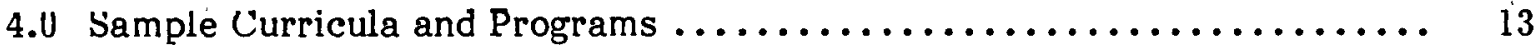

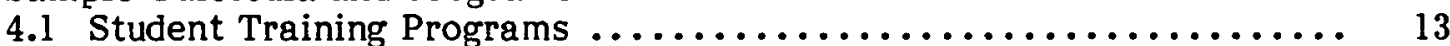

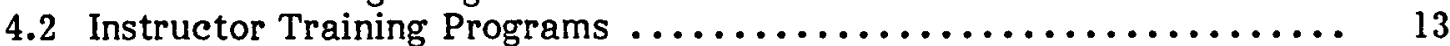

4.3 Classroom Source Materials ........................ 14

5.0 Equipment Needs for Solar Training...................... 15

5.1 Clark County Community College ...................... 15

5.2 Community College of Denver, Red Rocks Campus ............ 16

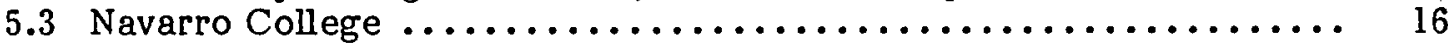

5.4 Scott Community College ......................... 16

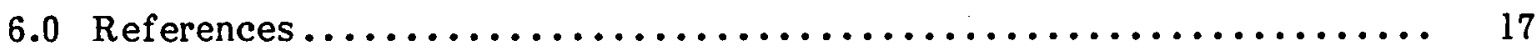

Appendix A - Solar Energy Task Force Members ................. Al

Appendix B - Predominant Solar Technician Tasks $\ldots \ldots \ldots \ldots \ldots \ldots \ldots \ldots \ldots$ Bl

Appendix $L-$ Predominant Solar Mechanic l'asks ................. Cl

Appendix D - Course Schedule $\ldots \ldots \ldots \ldots \ldots \ldots \ldots \ldots \ldots \ldots \ldots \ldots \ldots \ldots \ldots$ DI

Appendix E - Equipment List, Clark County Community College ......... El

Appendix F - Equipment List, Community College of Denver, Red Rocks Campus ............................. F1

Appendix G - Equipment List, Navarro College .................. Gl

Appendix $\mathrm{H}$ - Equipment List, Scott Community College............. Hl

Appendix I - Classroom Materials Sample, Community Collge of Denver,

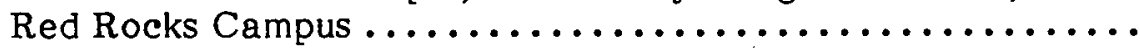




\section{SECTION 1.0}

\section{INTRODUCTION}

The Solar Energy Task Force met 12-13 September 1978 to develop directives for solar energy technical training programs. A group of twelve leaders in solar technical training represented education, labor, and business. See Appendix A for a list of the Task Force members.

This Task Force report offers guidelines for programs oriented to commercial applications in solar energy, specifically water and space heating. The report examines these technologies because they are, in some cases, economically feasible. Any new technical training program must be responsive to current market needs: jobs must be available ! Hence, concentration on other solar applications and alternate sources of energy was not considered. The Task Force report suggests sample curricula and programs, technical jobs and skills, and equipment to assist those institutions contemplating the development of technical training. Even though the report concentrates on active systems for space heating and hot water, a well-rounded program should focus early on energy conservation and the incorporation of passive design in new and existing buildings. 


\section{SEP愫}


SECTION 2.0

TASK FORCE SUMMARY

\subsection{OBJECTIVES}

The Solar Energy Task Force met to accomplish three goals that might provide information on technical training programs for people in education, labor, and business. The three objectives were:

- Solar Jobs and Associated Skills. The following jobs are those necessary for solar training programs: (a) Sales, (b) Designer, (c) Installer, (d) Electrician (not necessarily trained in the solar program, but needed in some solar installations), (e) Supervisor, and (f) Service/Maintenance Technician. Section 3.0 presents tasks and skills required for each job. A person may perform more than one job. These jobs might better be viewed as functions required in a solar installation. The size and complexity of the installation determine the jobs necessary.

- Sample Curricula and Programs for Students and Instructors. Institutions considering solar education of ten ask: Where do I start? What programs already exist? How do I get more information? Section 4.0 and Appendix I attempt to respond to these questions. Many curricula, programs, and courses are being offered across the United States [1,2]. The draft version of the Task Force report presented sample curricula from five selected schools. Since Refs. 1 and 2 are comprehensive, these curricula are not included in this revised version. Insufficient solar experience prohibits one from judging which program is the best. Different programs meet various needs. For example, an educational program that retrains already skilled individuals need not be as comprehensive as one for the high school graduate who needs training at the job entry level. Therefore, critical to program development is the selection of the target audience. In addition to student curricula, there is a need for programs directed toward instruction of the teacher. The programs for teachers offered at Colorado State University and the League for the Innovation of Community Colleges are described in Sec. 4.0 .

- Equipment Needs. Training requires special equipment for the classroom and laboratory. In emergent solar technology, there are only a few teaching programs and tested equipment for optimum classroom and laboratory experience. Section 5.0 and Appendices $\mathrm{E}$ through $\mathrm{H}$ suggest equipment that has been developed or proved useful. Although the purchase cost of solar equipment and teaching aids might be $\$ 20,000$, a cost of $\$ 50,000$ is probably not unreasonable for a well-equipped hands-on situation.

\subsection{CAUTIONS AND RECOMMENDATIONS}

In addition to the major objectives cited, many important issues were discussed, some of which directly impinge on the decision to offer solar courses.

- In general, the Task Force does not advocate that persons be educated strictly as solar technicians, mechanics, or installers, etc. Because the demand for purely solar jobs is uncertain, training a person for job entry as a "solar" anything might 
not assure employment. The direction of solar energy, however, may be dramatically altered with the passage of the National Energy Act, additional solar incentive legislation, state and local assistance, and other promotional activities. Were the Task Force to meet again within the coming year, it might advocate solar-specific job training. At the Community College of Denver, Red Rocks Campus, in Golden, Colo., where a two-year solar technician's training program is into its second year, Craig Hilton, Solar Energy Instructor, indicates that nearly all of his students find solar employment. But follow-up studies on continued employment in the solar field are necessary.

- When creating a solar program, an educational institution must understand the contents of the curriculum and coursework, the required tasks and competency levels for the personnel, and the equipment necessary for the solar laboratory. Sections 3.0 through 5.0 address those needs in detail.

- The terhnical training school should uso an Advisory Couneil composed of menbers of local industry, solar installers and contractors, labor organizations, building contractor's, etc. The Advisory Council serves these functions: (1) makes recommendations on solar programs related to technical training needs, (2) maintains awareness within the school of the manpower required in the solar market to help alleviate mistraining or overtraining, (3) provides speakers for programs, and (4) creates links with business and industry to facilitate job placement. Solar program offerings can be quite diverse in both content and length. A large portion of students enrolled in solar education programs are already gainfully employed and older than the average student. Each institution must consider the variety of solar jobs for which it could train students and whether each program will educate students at the job entry level, will retrain them, or will intensify their awareness of current solar applications.

- A person receiving solar training should be well-rounded in Heating, Ventilating, Air Conditioning (HVAC) and plumbing fundamentals. Schools and institutions already offering HVAC and plumbing programs can most easily expand to offer solar training. Students undergoing programs at the job entry level should be skilled in HVAC and plumbing with solar emphasis. In general, the Task Force held that solar specialization at the community or junior college level should be added only in response to community needs.

- The Task Force advocated that there was no need to educate a "solar" engineer. Engineers would be trained in a traditional discipline with specialization in solar energy, which would not preclude entrance into other lines of work. 


\section{SECTION 3.0}

\section{SOLAR JOBS AND ASSOCIATED SKILLS}

An educational institution should understand the variety of jobs for which students of solar energy need to be trained. Not every institution or program will educate students to be proficient in each of the jobs necessary for a successful solar installation. Some schools may offer only one or two courses that heighten community awareness, whereas others might give a full two-year curriculum that trains the "solar" mechanic or technician.

The Task Force identified six jobs that may be essential for solar installations. The jobs include the following: (1) Sales, (2) Designer, (3) Installer, (4) Electrician (not necessarily trained in the solar program), (5) Supervisor, and (6) Service (maintenance). Depending on his orientation and training, a person will be proficient in one or more of these jobs.

The tasks or skills associated with each job are detailed by the Task Force and will help to create curriculum tailored toward specific jobs. The jobs and their attendant skills are detailed in this section.

\subsection{SALES}

The salesman with insufficient solar knowledge will be detrimental to solar commercialization. Sales personnel must be knowledgeable about solar applications and should be able to perform the following activities.

\subsubsection{Describe Different Systems}

The sales person should be aware of all solar heating and cooling systems, including domestic hot water applications. They must also understand conventional HVAC and plumbing and the consonance of solar systems with various conventional types if solar retrofits are used. They must be able to properly match solar systems with HVAC systems.

\subsubsection{Show the Finished Product}

The sales person should explain the details of the finished system, including its appearance on the building, the location of its various components, and structural impacts of the system on the building.

\subsubsection{Explain Performance}

The sales person must describe the anticipated performance of the solar system, its operation with the conventional system, and its average energy deliverance to the building. The sales person must be able to demonstrate the expected energy savings of the system. 


\subsubsection{Recommend a Particular System}

The sales person must be sufficiently familiar with solar componentry to recommend an optimum system for each application. Knowledge of the most compatible components and of their successful size and design for system operation will also be necessary.

\subsubsection{Explain System Operation and Maintenance}

The sales person must clearly explain the various modes of operation. He should detail each mode and explain the method by which controls will activate the various modes; designate which pumps, motors, blowers will be active in each mode; and indicate the open/close positions of various valves and dampers for each system. The sales person must know the maintenance operations and intervals for each system installation.

\subsubsection{Explain Impact on Comfort}

The sales person must be able to explain any possible influence of the solar system on comfort. Potential impacts on humidity, time/temperature fluctuations, and noise levels should be explicated.

\subsubsection{Estimate System Costs}

The customer will be particularly interested in the additional cost of a solar system for a retrofit or the cost above the conventional system for a new installation. The sales person must know how to estimate costs of components, labor, energy usage, etc. An estimate of system savings on the energy bill and of investment payback periods must be attained.

The sales person must be knowledgeable of local, state, and federal solar incentive programs for tax credits, applicable rebates, etc. An understanding of lncal building oodes and insurance practices to solar construction will also be necessary.

\subsection{DESIGNER}

The system designer lays out the details of the solar system. The designer, therefore, will be the main interface between the project architect and mechanical engineer. The system designer will provide the intricacies that will insure successful system installation and interconnection with the conventional HVAC system. Therefore, detailed operational knowledge of conventional and solar systems is needed. The system designer must execute the dutles listed in Secs. 3.2.1 through 3.2.5.

\subsubsection{Select the Proper System}

From among the myriad solar systems available, the system designer must be able to select the system that best meets the building's heating/cooling load requirements, answers geographic considerations, integrates into the architectural design, complies with the maximum structural stress for the area in which the system is integrated, and meets local code requirements. 


\subsubsection{Select Optimum System Size}

Even though larger systems with properly sized storage will yield more energy to the consumer, there is a point on the cost/benefit scale beyond which it is imprudent to invest in a larger system. (In addition, available collector surface area may be exceeded). The system designer must select the optimum system size based on his knowledge of its performance and of system economics. The method of calculating optimum system size and the appropriate tools (usually computer/calculator program) for the job (for example, FCHART, SOLCOST, etc.) must be part of the designer's repertoire.

\subsubsection{Calculate System Performance}

The system designer should be able to calculate system performance for any geographic location. He should know how to calculate building heat loads for sizing the system (Section 3.2.2) and how to merge this information into the predicted energy savings of the solar system. Tools that help one to select optimum solar system size such as FCHART and SOLCOST, are useful in calculating system performance [3] .

\subsubsection{Provide Details on Operation}

The system designer must be able to create the necessary drawings, charts, tables, etc., which size and locate solar system components in the buildings. Drawings and charts should sufficiently explain the various modes of operational detail for the architect and mechanical engineer. The detailed drawings should also be complete enough to be used by the installer, electrician, supervisor, and maintenance persons. The operational detail will include the following:

- Specific drawings and descriptions of each mode of operation, including location of ducts, dampers, valves, etc. for the particular mode;

- Operational ranges of system controls for each mode;

- Collector placement, altitude and azimuth angles, and attachment to building struc ture;

- Detailed drawings and descriptions of piping and duct connections, sizing, flow balancing, etc.;

- Component sizing and location of collectors, pumps, blowers, and storage; and

- Meticulous drawings and descriptions of the storage component and interconnections.

\subsubsection{Describe Installation and Maintenance}

The information itemized in Sec. 3.2.4 should provide details necessary for the system installer. In addition, the system designer should describe the routine anticipated maintenance operations and attendant schedules. 


\subsection{INSTALLER}

System installers will need to intricately understand installation and construction of solar component hardware, as well as HVAC and plumbing systems. In addition; they should have a specific knowledge of system operation, design, maintenance, and local building codes. The installer is the hands-on person capable of translating the designer's blueprints into a properly installed system. The installer should demonstrate good craftsmanship in all his work and toward this end should be able to perform the activities given next.

\subsubsection{Install Collectors}

The installer must be familiar with a variety of installation techniques, mounting hardware, and collector interconnections. The installer must be able to mount, fasten, and flash collectors to insure that collectors and support structures will withstand the local climate (wind, hail, snow, etc) and prevent roof leakage and rot.

\subsubsection{Make System Connections to Collectors}

The installer must be totally familiar with the necessary connections in each solar system, including both air and liquid. The installer must know the various fittings and unions and the soldering and sheet metal techniques used in making connections. To assemble collectors and establish system connections, one must understand and incorporate allowances for thermal expansion.

\subsubsection{Test for Leakage}

Prior to installation, collectors should be tested for both internal leakage in the absorber plate and external leakage through the collector housing. The installer must also be able to flush a liquid system, fill it with the appropriate fluid, and pressure test it for leaks.

\subsubsection{Locate, Construct, and Install Storage}

The installer should be familiar with various storage systems, containers, tanks, etc., that can be employed in solar systems. The installer should be able to construct storage systems, usually rock storage bins with air systems. One should know the proper locations for the tank or storage bin, i.e., allow room for interconnections, insulation, servicing, etc.

\subsubsection{Connect Pipes and Ducts to Storage}

The installer must be able to read designer blueprints to connect pipes and air ducts to the storage container, which includes (in addition to Task 3.3.2) the proper pitching of pipes and use of appropriate insulation (right type and R-Value) of pipes and ductwork. This task would also involve the installation of storage sensors connected to the system controller. 
3.3.6 Install Collector/Storage Heat Exchangers, Pumps, Check Valves, Filters, Isolation Valves, and Other Hardware that Affects the Collector/Storage Operation.

3.3.7 Connect the System with a Standard Backup Heating Unit, Including Filters, Humidifiers, etc.

\subsection{ELECTRICIAN}

The electrician will be used for the installation of solar controls. He may be unfamiliar with the detailed operation of solar systems, but he should be able to interpret the system information (drawings, blueprints, etc.) for successful hookup of the solar control system. On smaller systems, usually retrofits, an electrician may be unnecessary because there is no need to connect wiring to the main service box or to work directly with the 110 vac lines. In larger systems, especially those of commerce and industry, an electrician will be needed. The electrician must be trained to perform the following duties.

\subsubsection{Provide Power To Main Control Unit, Blowers, Pumps, and Any Safety Controls in} the Sytems

\subsubsection{Install Sensors Or Insure That They Are Properly Installed}

\subsubsection{Install Thermostat}

\subsubsection{Connect Mechanical Device Controls to Controller}

\subsubsection{Cheek Out Control Modes with the Person Responsible for System Startup}

\subsection{SUPERVISOR}

The supervisor of the construction and installation of solar systems will need to perform these tasks.

\subsubsection{Establish a Schedule}

The supervisor will need to coordinate the delivery of materials with manpower schedules to insure that the installation proceeds smoothly.

\subsubsection{Conform with Codes}

The supervisor must be certain that the solar installation does not violate any of the 10cal building codes, ordinances, etc. 


\subsubsection{Conform Installation with Design}

The supervisor must continuously inspect the system being installed to insure that it is without variance, unless approved, to the original system design.

\subsection{SERVICE AND MAINTENANCE TECHNICIAN}

The service or maintenance technician needs to be erudite about solar system operations. The service person must be able to perform the activities included in Secs. 3.6.1 through 3.6.9.

\subsubsection{Understand the General System Operation}

Before tackling maintenance, the service technician must have a practical knowledge of each system.

\subsubsection{Identify the Control Modes of the System}

The technician should know controller circuitry and associated wiring, the proper location and installation of sensors, and the temperature ranges and control points of system modes.

\subsubsection{Determine If Mechanical Devices are Operational}

The service person must have experience with motor repair and operation and with various valves (gates, balancing, pressure-temperature relief, air vents, solennid, etr..).

\subsubsection{Identify Points for Fluid Temperature Measurements}

He must be able to determine if sensors are properly installed and in the proper locations.

\subsubsection{Determine if Heat Flows are Nominal}

Also, he must know the principles of heat transfer and make calsulatinns haser nn temperature measurements to determine if the actual heat flows as compared to theoretical flows are within the acceptable tolerances.

\subsubsection{Locate Problems}

'The technician must coordinate system knowledge, system operation, and testing and measuring techniques to localize any problems. 


\subsubsection{Solve Problems}

When the problem is isolated the maintenance person should solve it. In some instances, he may have isolated the problem, but will be unable to repair it himself. He then must know the person to contact to correct the trouble.

\subsubsection{Execute Periodic Maintenance}

The service person should maintain pumps, motors, blowers, and anti-freeze, depending on the system type. Changes of filters and system flushing may be needed in certain systems. The maintenance person should perform all maintenance specified by the system designer.

\subsubsection{Perform System Startup}

On small system installations (swimming pool and domestic hot water), system startup will be done by the service/maintenance person. Ability to perform the above tasks should assure proficiency in correcting problems of smaller systems. In larger, more complex systems, especially in commerce and industry, system startup will be performed by one knowledgeable in large-scale applications, and informed about total system operation (design function), installation, electrical operation, and service/maintenance requirements. Assurance that the system is properly operating is the task of the system startup person. In large systems, this person (who may be the mechanical contractor) may be supervising a team as the system is engaged.

Section 3.0 has focused on six jobs. An al ternate approach to classification of jobs and tasks was done in a master's thesis by William D. Hunt of California State University at Chico, Calif., titled "Solar Technicians and Mechanics: a Preliminary Occupational Task Analysis." Given in this thesis are detailed task requirements for two jobs in the emerging solar heating and cooling industry. Appendices B \& $\mathrm{C}$ list predominant solar technician and mechanic tasks. 


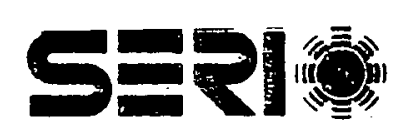




\section{SECTION 4.0}

\section{SAMPLE CURRICULA AND PROGRAMS}

\subsection{STUDENT TRAINING PROGRAMS}

When the Task Force report was originally written in draft form, the National Solar Energy Education Directory, First Edidtion [1] and the Solar Energy Technical Training Directory [2] were not yet in print. With the avail ability of these reports, it is unnecessary to list solar curricula, programs, and courses. Anyone interested should consult these documents.

\subsection{INSTRUCTOR TRANNING PROGRAMS}

- Department of Energy - Community College Instructor Training

Contact: Debra Langford (202) 376-1983. Conservation and Solar Applications, DOE, Room 222 1C, 20 Massachusetts Avenue, N.W., Washington; D.C. 20545.

Under contract with DOE's Solar Technology Transfer Program, the League for Innovation in the Community College, a national consortium representing 50 cor leges, is developing curriculum material and procedures for training community college instructors who must teach solar installation skills. Specifically, the project will:

- Train a minimum of 60 community college vocational/technical faculty members from 9 districts ( 38 colleges) in the western United States to teach skills necessary for the installation of solar systems.

- Train two-member teams from the nine districts to develop and implement training programs for solar system installers.

- Duplicate the program for Eastern/Midwestern community college districts from the results of the Western Region Program.

- Explore training by television for solar system installers.

- Develop a training format for installers.

- Establish a network for the community college districts to share information about solar systems.

- Colorado State University

Contact: Dr. Susumu Karaki, Director, Solar Energy Applications Laboratory, Colorado State University, Fort Collins, Colo. 80523.

The Colorado State University's Solar Energy Applications Laboratory has developed two of the most comprehensive manuals for training the solar instructor and practitioner. The titles are: Solar Heating and Cooling of Residential Buil dings: Sizing, Installation and Operational Guidelines [4], and Solar Heating and Cooling of Residential Buildings: Design of Systems [5]. The modular course has been offered in one week schedules (See Appendix D), but some schools are using the manuals, with supplemental information, as the basis for training programs. Each manual is over 700 pages. 


\subsection{CLASSROOM SOURCE MATERIALS}

Books and documents are available for the technical training classroom. One should review a sample of source materials used in an actual program, such as that of the Community College of Denver, Red Rocks Campus (Appendix I). A more detailed "Reading List for Solar Energy" (latest edition) can be obtained from the National Solar Heating and Cooling Information Center, P.O. Box 1607, Rockville, MD 20850. 


\section{SECTION 5.0}

\section{EQUIPMENT NEEDS FOR SOLAR TRAINING*}

The cost and process of setting up a laboratory for solar training has varied greatly from institution to institution. In general, the Task Force agreed that for approximately $\$ 20,000$ an effective solar laboratory could be initiated. If the entire funding is not available in the beginning of a program, it is proposed that the equipment be purchased in stages. The suggested costs of equipment for the sample schools listed are summarized:

School

Clark County Community College, North Las Vegas, Nev.

Community College of Denver - Red Rocks Campus, Golden, Colo.

Navarro College, Corsicana, Tex.

Scott Community College, Bettendorf, Iowa
Solar Equipment Costs

$\$ 57,275$

$\$ 21,000$

$\$ 45-\$ 55,000$

$\$ 54,000$

Because solar educational offerings are embryonic, development of standard laboratory equipment for solar energy is also in its infancy. Sample lists of major equipment that are in use or are planned for technical training programs in several community colleges are presented. The emphasis is on hands-on equipment, models, and diagnostic training aids.

\subsection{CLARK COUNTY COMMUNTTY COLLEGE}

Highly innovative equipment is used in the Clark County Community College Solar Program. All equipment is designed to promote a logistically integrated educational program. Much of it centers around a Central Control Monitoring Package (CCMP). This unit can control most active solar systems, from the simplest to the most complex, as well as collect and record data from various energy systems. Designed and built especially for Clark County Community College is the unique Modular Liquid System Trainer (MLST), having totally interchangeable components of tanks, pumps, valves, heat exchangers, pipes, etc. Any assembled system can be monitored and controlled with the CCMP.

Useful collector arrays consist of various liquid collectors including a simple unglazed swimming pool type, a single-glazed nonselective flat plate, a double-glazed selective flat plate, an evacuated tube module, and a concentrating parabolic tracker. Air systems may be simulated with a unique $1 / 8$ scale Model Air System. By the use of model passive homes and temperature monitoring through the CCMP, passive solar systems may be studied. For practical experience in installing and maintaining solar swimming pool collectors, a simulated roof-mounted solar swimming pool collector unit is provided at

*Any reference to specific manufacturers or products is not an endorsement of any product or service, but is listed for information purposes nnly. 
ground level to assemble, repair, and disassemble. Apparatuses and prices used in the Clark County Community College Program are found in Appendix E.

\subsection{COMMUNITY COLLEGE OF DENVER, RED ROCKS CAMPUS}

The list of equipment for the Certificate and Associate Degree Program of the Community College of Denver, Red Rocks Campus, is found in Appendix F.

\subsection{NAVARRO COLLEGE}

Navarro College off ers the one-year solar mechanics program and expects to offer the solar technician program in the fall of 1979. A list of major equipment proposed by Navarro College is found in Appendix r.

\subsection{SCOTT COMMUNITY COLLEGE}

The equipment list used by Scott Community College for their technical training program is presented in Appendix $\mathrm{H}$. 


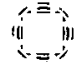

\section{SECTION 6.0}

\section{REFERENCES}

1. Corcoleotes G.; Kramer K.; O'Connor K.; Silversmith J. National Solar Energy Education Directory, First Edition. Golden, CO: Solar Energy Research Institute. SERI/SP-42-141; Jan. 1979. Available from: Superintendent of Documents, U.S. Government Printing Office, Washington, D.C., 20402, 061-000-00210-3. Price: $\$ 4.75$.

2. Corcoleotes G.; Kramer K.; O'Connor K. Solar Energy Technical Training Directory. Golden, CO: Solar Energy Research Institute. SERI/SP-84-282; June 1979. Available from: SERI Document Distribution Service, 1536 Cole Blvd., Golden, CO. 80401 and the National Solar Heating and Cooling Information Center, P.O. Box 1607, Rockville, MD 20850.

3. Solar Energy Research Institute. Analysis Methods for Solar Heating and Cooling. Golden, CO. SERI/SP-35-232. Available from: SERI Document Distribution Service, 1536 Cole Blvd., Golden, Colo. 80401.

4. Solar Energy Applications Laboratory. "Solar Heating and Cooling of Residential Buildings: Sizing, Installation and Operation of Systems. Fort Collins, CO: Colorado State University; Jan. 1977. Available from: Superintendent of Documents, U.S. Government Printing Office, Washington, D.C. 20402, S/N 003-011-00085-2. Price: $\$ 8.25$.

5. Solar Energy Applications Laboratory. Solar Heating and Cooling of Residential Buildings: Design of Systems. Colorado State University, Solar Energy Applications Laboratory; Jan. 1977. Available from: Superintendent of Documents, U.S. Government Printing Office, Washington, D.C., 20402, S/N 003-011-00084-4. Price: $\$ 7.50$. 


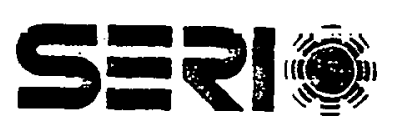


APPENDIX A

SOLAR ENERGY TASK FORCE MEMBERS

A 1 
SEPI羳 
Mr. O.C. Burnell

Director of Instruction

Scott Community College

Belmont Road

Bettendorf, Iowa 52722

(319) 359-7531

Mr. Peter Colaianni

Solar Energy Industries Association

1001 Connecticut Avenue, N.W., Suite 800

Washington, D.C. 20036

(202) 293-2984

Mr. David Comarow

Clark County Community College

3200 East Cheyenne Avenue

North Las Vegas, Nev. 89030

(702) 643-6060, Ext. 396

Mr. David E. Herrington (not in attendance)

Admin. Assistant for Technological

and Educational Programs

National Training Fund

Sheet Metal and Air Conditioning Industry

1900 L Street, N.W., Suite 405

Washington, D.C. 20036

(202) 833-9543

Mr. Craig A. Hilton

Community College of Denver

Red Rocks Campus

12600 West 6 th Avenue

Golden, Colo. 80401

(303) 988-6160, Ext. 225

Mr, Robert N. Illingsworth

Director, Research \& Development

Eastern Iowa Community College District

2804 Eastern Avenue

Davenport, Iowa

(319) 322-5015
Dr. Susumu Karaki, Director

Solar Energy Applications Laboratory

Colorado State University

Fort Collins, Colo. 80523

(303) 491-8617

Mr. Robert Martinez

National Training Fund

Sheet Metal and Air Conditioning Industry

1656 S. Jellison Street

Lakewood, Colo. 80226

(303) 986-8990

Mr. Kevin $\mathrm{O}^{\prime}$ Connor

Task Force Chairperson

Solar Energy Research Institute

1617 Cole Boulevard

Golden, Colo. 80401

(303) 231-1825

Mr. Allyn Parmenter, Director

United Assn. of Journeymen \& Apprentices of the Plumbing \& Pipe Fitting Ind. of the United States and Canada

901 Massachusetts Avenue, N.W.

Washington, D.C. 20001

(202) 628-5823

Mr. Robert Zimbelman

Manager of Education Program Development

Education Department

Lennox Industries, Inc.

Promenade Tower

Box 400450

Dallas, Tex. 75240

(214) 783-5230

Ms. Revonda Williams (DOE Coordinator)

Education Programs Division

Department of Energy

400 First Street, N.W., Room 307

Washington, D.C. 20545

(202) 376-9211 


\section{SEPr}

$\$$ 
APPENDIX B

PREDOMINANT SOLAR TECHNICIAN TASKS

Bl 


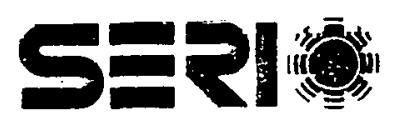


Solar Technician Task Requirements ${ }^{a}$

- Read blueprints and schematics.

- Calculate heat loss/gain in buildings.

- Size solar collector array.

- Prescribe appropriate automatic solar controls.

- Size water storage sub-systems.

- Draft blueprints and schematics.

- Perform supervisory functions.

- Trouble-shoot, maintain, and repair solar controls.

- Size or prescribe solar plumbing, to include pumps, based on "rule of thumb" procedures.

- Size solar-assisted heat-pump systems.

- Size auxiliary backup heating systems.

- Size or prescribe solar plumbing, to include pumps, based on flow rates, friction loss, and other data.

- Size heat exchanger units.

- Size rock storage subsystems.

- Sell solar apparatus.

- Size or prescribe solar pond or solar wall (thermal mass) systems.

- Size south-facing window systems.

- Prescribe types of movable insulation and apparatus in passive systems.

- Perform administrative functions.

- Calculate heat loss/gain in storage systems.

- Maintain and repair solar collector array.

- Design duct work requirements.

${ }^{a}$ From Hunt, William D. Solar Technicians and Mechanics: A Preliminary Occupational 'l'ask Analÿsis. San Dlegu, CA, 7283 Engineer Rd., Suite -G: Southwest Energy Mangement, Inc. 


\section{Solar Technician Task Requirements (concluded)}

- Size or prescribe heating ducts, vents, and blowers based on "rule of thumb" procedures.

- Size or prescribe heating ducts, vents, and blowers based on flow rates, friction loss, and other data.

- Calculate heat loss/gain in plumbing and duct systems.

- Maintain and repair solar plumbing. 
APPENDIX C

PREDOMNNANT SOLAR MECHANIC TASKS 


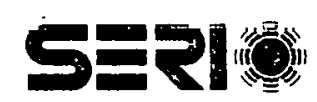


Solar Mechanic Task Requirements ${ }^{\mathrm{a}}$

- Install and wire solar control systems.

- Read blueprints and schematics.

- Cut and join plastic pipe/plumbing.

- Install solar collectors on roofs.

- Maintain and repair solar collector array.

- Maintain and repair solar plumbing.

- Maintain and repair solar blowers and fans.

- Cut and braze copper pipe/tubing.

- Install prefabricated sheet metal parts.

- Install solar collector array or solar furnace at ground level.

- Maintain and repair solar water pumps.

- Iristall water storage sub-systems.

- Install living area/space heat exchanger units.

- Build and install rock storage sub-systems.

- Install solar-pond or solar-wall (thermal mass) systems.

- Soft-solder electrical wires and connections.

- Install auxiliary backup heating systems.

- Modify existing furnace to accept solar apparatus.

- Cut and install glass or plastic glazing in collectors.

- Install movable insulation and apparatus in passive systems.

- Modify or relocate existing plumbing and exhaust vents on roof.

- Install heating ducts and vents.

- Install solar-assisted heat pumps.

- Trouble-shoot, maintain and repair solar controls.

- Silver braze copper alloy pipe and sheets.

- Cut, bend, and fabricate sheet metal parts.

- Perform supervisory functions.

- Cut, thread, and install galvanized pipe/plumbing.

$a_{\text {From Hunt, William D. Solar Technicians and Mechanics, a Preliminary Occupational }}$ Task Analysis. 


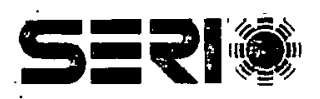




\section{APPENDIX D \\ COURSE SCHEDULES \\ COLORADO STATE UNIVERSITY}




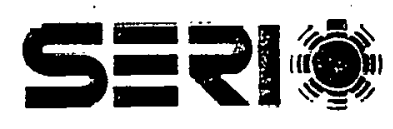




\begin{tabular}{|c|c|c|c|c|c|c|}
\hline & SUNDAY & HONDAY & TUESDAY & MEDNESOAY & THURSDAY & FRIDAY \\
\hline \multirow[t]{2}{*}{ C800 } & & $\begin{array}{l}\text { MOD.JLE } 2 \text { (45 min) } \\
\text { Course Orientation }\end{array}$ & $\begin{array}{l}\text { OPEN DISCUSS ION } \\
(30 \mathrm{~min})\end{array}$ & $\begin{array}{l}\text { OPER OISCUSSION } \\
(60 \mathrm{~min})\end{array}$ & $\begin{array}{l}\text { OPEN DISCUSSION } \\
(30 \mathrm{~min})\end{array}$ & $\begin{array}{l}\text { OPEN DISCUSSION } \\
(30 \min )\end{array}$ \\
\hline & & $\begin{array}{l}\text { MOOULE } 3(75 \mathrm{~min}) \\
\text { Introduction to } \\
\text { Solar HLC Systems }\end{array}$ & $\begin{array}{l}\text { ROOULE } 6(90 \mathrm{mini} \\
\text { Thermal storage } \\
\text { Subrsyst tems }\end{array}$ & $\begin{array}{l}\text { Mooule } 10(60 \mathrm{~m} / \mathrm{n}) \\
\text { Solar Heating and } \\
\text { Coavilng Systems } \\
\end{array}$ & $\begin{array}{l}\text { Mooule } 13(90 \mathrm{~min}) \\
\text { Heat ing Lodd Calcula. } \\
\text { tions }\end{array}$ & $\begin{array}{l}\text { MOOULE } 17(90 \mathrm{~min}) \\
\text { cost Eff fectiveness of } \\
\text { Energy Conservation }\end{array}$ \\
\hline \multirow[t]{3}{*}{1000} & & COFFEE $(30 \mathrm{~min})$ & COFFEE $(30 \mathrm{~m} / \mathrm{n})$ & COFFEE $(30 \mathrm{~m} / \mathrm{n})$ & COFFEE $(30 \mathrm{~m} / \mathrm{h})$ & COFFEE $(30 \mathrm{~m} / \mathrm{n})$ \\
\hline & & $\begin{array}{l}\text { Monule 4. (90 min) } \\
\text { Solar Radiation }\end{array}$ & $\begin{array}{l}\text { MOOULE } 7(90 \mathrm{~min}) \\
\text { Servitee Hot Hater } \\
\text { Systems }\end{array}$ & $\begin{array}{l}\text { MODJLE } 11 \text { (45 min) } \\
\text { Control Subsystems }\end{array}$ & $\begin{array}{l}\text { Mooulc } 14(60 \mathrm{~min}) \\
\text { Solar system sizing }\end{array}$ & $\begin{array}{l}\text { MooulE } 18 \text { (45 } \mathrm{min}) \\
\text { Retroffit Considerd- } \\
\text { tlons }\end{array}$ \\
\hline & & & & $\begin{array}{l}\text { MOOULE } 12 \text { (455 min) } \\
\text { Operat tons Loboratory }\end{array}$ & $\begin{array}{l}\text { MOOULE } 15(30 \mathrm{~m} / \mathrm{n}) \\
\text { System Economics }\end{array}$ & $\begin{array}{l}\text { Hooule } 19 \text { (95 } \mathrm{mm} \text { ) } \\
\text { Schedulu ing of Solar } \\
\text { Installations }\end{array}$ \\
\hline $\begin{array}{l}1200 \\
1300\end{array}$ & & LUNCH (60 m/a) & LUNCH $(60 \mathrm{~m} / \mathrm{n})$ & LUKCH $(60 \mathrm{~m} / \mathrm{n})$ & LUACH $-(60 \mathrm{~m}(\mathrm{n})$ & LUNCH $(60 \mathrm{~m} / \mathrm{n})$ \\
\hline 1300 & & $\begin{array}{l}\text { MODULE } 4 \text { cont }(60 \mathrm{~m} / \mathrm{n}) \\
\text { Solar Radiation }\end{array}$ & $\begin{array}{l}\text { Mooule \& (120 min }) \\
\text { Solar Heating Sys ters }\end{array}$ & $\begin{array}{l}\text { MooulE } 12 \text { cont (240mm } 1 \mathrm{~m}) \\
\text { Operations Loboratory }\end{array}$ & $\begin{array}{l}\text { Mooul E } 15 \text { cont }(30 \mathrm{mmm} \\
\text { System Economics }\end{array}$ & $\begin{array}{l}\text { MOQuLE } 20(60 \mathrm{mln}) \\
\text { Construlnes and } \\
\text { Incentives }\end{array}$ \\
\hline 400 & $\begin{array}{l}\text { REGISTRATION } \\
\text { Solar House Tours }\end{array}$ & 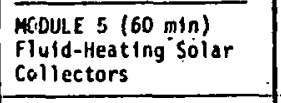 & & & $\begin{array}{l}\text { Mopule } 16(90 \text { min) } \\
\text { Solar system sizing } \\
\text { Calculations } \\
\end{array}$ & $\begin{array}{l}\text { MOOULE } 21 \text { (60 } \mathrm{m} / \mathrm{n}) \\
\text { Buyer's Guidde }\end{array}$ \\
\hline \multirow[t]{2}{*}{1500} & & COFFEE $(30 \mathrm{~min})$ & COFFEE $(30 \mathrm{~min})$ & & COFFEE $(30 \mathrm{~m} / \mathrm{n})$ & COFFEE $(30 \mathrm{~m} / \mathrm{n})$ \\
\hline & & $\begin{array}{l}\text { MoOuLE } 5 \text { cont }(90 \mathrm{~min}) \\
\text { Fivid-heating solar } \\
\text { callectors }\end{array}$ & $\begin{array}{l}\text { mopule } 8 \text { cont }(30 \mathrm{~min}) \\
\text { Solar Heat Ing Systens } \\
\begin{array}{l}\text { MoDule } 9(60 \mathrm{~min}) \\
\text { Solar space coo) ing } \\
\text { systems }\end{array} \\
\end{array}$ & - & $\begin{array}{l}\text { MoOULE } 16 \text { cont }(90 \mathrm{mln}) \\
\text { Solar system sizlng } \\
\text { calculatitions }\end{array}$ & $\begin{array}{l}\text { Final Discuss } 1 \text { ion } \\
\text { and Crit lque }(90 \mathrm{~m} / \mathrm{n})\end{array}$ \\
\hline \multirow{2}{*}{$\begin{array}{l}1700 \\
1730\end{array}$} & & PDJOURN & ADJOURN & ADJOURN & ADJOURN & ADJOURM \\
\hline & $\begin{array}{l}\text { RECEPTIOH AND DIHNER } \\
\text { MODULE I }(30 \mathrm{~m} \text { (n) } \\
\text { Energy Problem }\end{array}$ & & . & & & $\begin{array}{l}\text { AHARDS DINNER } \\
\text { MODULE } 22 \\
\text { Future Prospects for } \\
\text { Solar HSC SYstems }\end{array}$ \\
\hline
\end{tabular}




\begin{tabular}{|c|c|c|c|c|c|}
\hline SUMDAY & noNoAY & TuEsear & MEONESDAY & THURS DAY & FRJDAY \\
\hline & $\begin{array}{l}\text { Hooule } 1 / 30 \mathrm{~min}) \\
\text { Course Orientation }\end{array}$ & $\begin{array}{l}\text { REVIEM AHD QUEST TOHS } \\
(30 \mathrm{~m} / \mathrm{n})\end{array}$ & $\begin{array}{l}\text { REV!EW AND QUESTIOHS } \\
(30 \mathrm{~min})\end{array}$ & $\begin{array}{l}\text { REVIEW AND QUT.STIONS } \\
(30 \mathrm{~m}(\mathrm{n})\end{array}$ & $\begin{array}{l}\text { REVIEW AND QUESTIONS } \\
(30 \mathrm{~min})\end{array}$ \\
\hline & 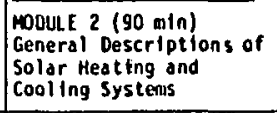 & 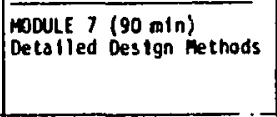 & $\begin{array}{l}\text { Howle } 11(90 \mathrm{am}) \\
\text { Collectors }\end{array}$ & $\begin{array}{l}\text { Module } 15 \text { (90 riin) } \\
\text { System Contros }\end{array}$ & $\begin{array}{l}\text { PouviE } 20(90 \text { a }(n) \\
\text { Design Case Study }\end{array}$ \\
\hline & COFFEE $(30 \mathrm{~m} / \mathrm{n})$ & COFFEE $(30 \mathrm{mtn})$ & COFfEe $(30 \mathrm{~m} / \mathrm{n})$ & COFffE $(30 \mathrm{ml} / 4)$ & COFFEE $(30 \mathrm{~min})$ \\
\hline & \multirow{3}{*}{$\begin{array}{l}\text { Hooule } 3(90 \mathrm{mln}) \\
\text { Solar padiat in Infor- } \\
\text { mation for does ign } \\
\text { purposes }\end{array}$} & 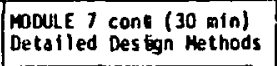 & $\begin{array}{l}\text { mooul il cont }(30 \mathrm{~min}) \\
\text { collectors }\end{array}$ & \multirow{3}{*}{ 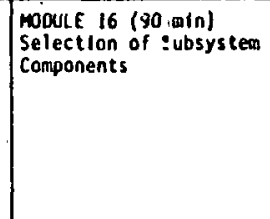 } & 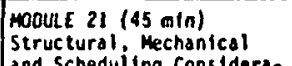 \\
\hline & & YODULE \& $(60 \mathrm{~min})$ & OODULE $12(60 \mathrm{Q} / \mathrm{n})$ & & tions \\
\hline & & teconomic consoerdetions & prorage systems & & $\begin{array}{l}\text { Hooulte } 22(45 \text { min) } \\
\text { Future Prospects for solar } \\
\text { Heating and cool ing } \\
\text { systems }\end{array}$ \\
\hline & LUKCH $(60 \mathrm{~m} / \mathrm{n})$ & LURCH $(60 \mathrm{~min})$ & LLWCH (60 a1n) & LUHCH $(60 \mathrm{~min}$ ) & :LUKCH $(60 \mathrm{~min})$ \\
\hline \multirow{2}{*}{$\begin{array}{l}1400 \text { - Registration } \\
2445 \text { - Solar House } \\
\text { Tours }\end{array}$} & 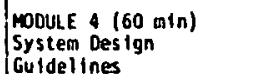 & \multirow{2}{*}{$\begin{array}{l}\text { Module } 9(120 \mathrm{~min}) \\
\text { Energy Conservation } \\
\text { rrade- of fs }\end{array}$} & \multirow[t]{2}{*}{$\mid \begin{array}{l}\text { Hooue } 13(120 \text { aln }) \\
\text { Loboratory }\end{array}$} & \multirow[t]{2}{*}{$\begin{array}{l}\text { Mopule } 17 \text { (122 aln) } \\
\text { Solar cool ing systems }\end{array}$} & $\begin{array}{l}\text { Mooule } 23(60 \mathrm{~m} / \mathrm{n}) \\
\text { Buyer's Guide }\end{array}$ \\
\hline & $\begin{array}{l}\text { Mooule } 5 \text { (60 Hin) } \\
\text { Heating and cooling } \\
\text { Lodd Analyses }\end{array}$ & & & & $\begin{array}{l}\text { Revilew and Sumary } \\
(60 \mathrm{~m}(\mathrm{n})\end{array}$ \\
\hline & COFFEE $(30 \mathrm{~m} / \mathrm{n})$ & COFFEE (30 m/G) & COFfEE $(30 \mathrm{~min})$ & COFFEE (30 mint & COFFEE (30 由/n) \\
\hline & 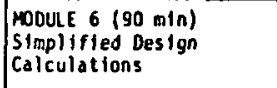 & $\begin{array}{l}\text { HODULE } 10(90 \mathrm{~m} / \mathrm{n}) \\
\text { Detasled Design } \\
\text { Calculations }\end{array}$ & 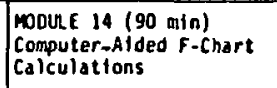 & $\begin{array}{l}\text { MoDule } 18(45 \mathrm{nin}) \\
\text { Automated Desi gn } \\
\text { Techniques }\end{array}$ & $\begin{array}{l}\mid \begin{array}{l}\text { Evaluation of the Course } \\
\text { by participants }\end{array} \\
\end{array}$ \\
\hline & & & & $\begin{array}{l}\text { HoDule } 19(45 \text { nin) } \\
\text { Service Hot Ho:er } \\
\text { Systems }\end{array}$ & \\
\hline & AWJOURN & ADJOURM & ADJOURN & ADJOURN & ADJOURN \\
\hline Reception ind Dinner & & & & & Dinner and Awards \\
\hline
\end{tabular}


APPENDIX E

EQUIPMENT LIST

CLARK COUNTY COMMUNITY COLLEGE 


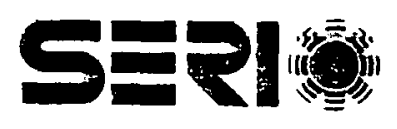


Supplied by David Comarow ${ }^{\mathrm{a}}$

Instrumentation

$\underline{\text { Price }}$

Flow meters, strip chart recorder

$\$ 2,500$

Calculator, with Sof tware

6 Computer Terminals

7,100

Hand tools

2,700

Simula tors $^{b}$

Controller Bread Board Trainer

2 Modular Liquid System Trainers (MLS)

38,000

2 Central Control Monitoring Packages (CCMP)

Omnidata Solar Simulator

Model Air System

Collector Arrays and Installation - 5 collectors

6,400

$\$ \overline{58,275}$

In addition to the above equipment, Clark County Community College paid $\$ 12,000$ to the Desert Research Institute for a needs assessment study, a program assessment study, and the development of three computer programs used in the training program.

${ }^{a_{S}}$ See Appendix A for contact information.

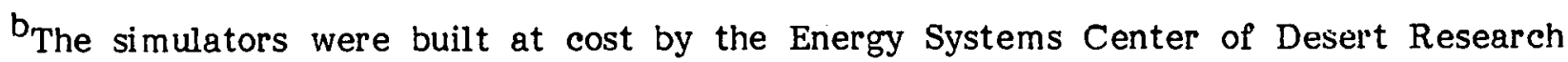
Institute. 


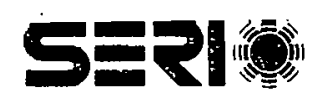




\author{
APPENDIX F \\ COMMUNITY COLLEGE OF DENVER \\ RED ROCKS CAMPUS \\ SOLAR ENERGY INSTALLATION AND MAINTENANCE PROGRAM
}




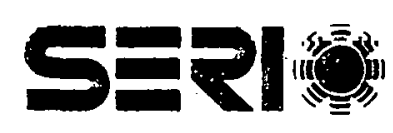


Supplied by Craig Hiiton ${ }^{8}$

Instruments

2 Heliotrope General Strip Chart Recorders, Model SCR-10

2 Heliotrope General Electronic Thermometers, Model ET 10

1 Heliotrope General Thermometer, Model ET/DT3

1 Heliotrope General Thermometer, Model HH-230

Assortment of Heliotrope General Sensors

1 Texas Instrument TI-59 Programmable Calculator

1 Printer for above calculator, Model PC-100A

1 Hastings Air Meter, Model 6-11

1 Extension cable for above meter, Model CF-12-CM

I T.I.F. Volume-Aire Air Balancer, Model VA-105

1 Rho Sigma Photovol taic Pyranometer, Model RS1008

I Rho Sigma Single Track Recorder for above, Model RS 1009

2 Heliotrope General Electronic Thermometers, Model ET0/350

Heli otrope General TES-1 Sensors

1 Meter-Master Digital Mul timeter, Model 461

Subtotal
Cost

$\$ 780.00$

258.00

96.00

83.00

100.00

270.00

180.00

150.00

14.00

100.00

135.00

280.00

200.00

100.00

150.00

$\$ 2,896.00$

Equipment:

1 Grumman Domestic Hot Water Package, Model 60FFT

2 Grumman double glazed collectors, Model 60F

8. Sungrabber 2'x10' Collectors with Black Chrome Rocky Mountain Products, Denver, Colo.

1 Domestic Hot Water System, Lordan Collectors (three), Mountain Mechanical Sales, Denver, Colo.

2 Solaron Air Collectors plus mounting hardware, Model

CL 2003X, Capture Energy Products, Inc., Denver, Colo.

2 Solaron Air Collectors plus mounting hardware, Model

CL 2003Y, Capture Energy Products, Inc., Dener, Colo.

1 Solar Air Handling Init with thermostat and controls

5 Misc. Delta Ts and other components

$180 \mathrm{Gal}$. Sepco Storage tank with removable heat

exchanger, Capture Energy Products, Inc., Denver, Colo.

1 Domestic Hot Water System, including 2 Insolarator

Collectors, Model SA1 20-1255, Mountain Mechanical Sales,

Denver, Colo.

$\$ 1,150.00$

550.00

$2,500.00$

$1,156.00$

$1,175.00$

$1,175.00$

300.00

500.00

504.00

$1,100.00$

Subtotal

$\$ 10,110.00$

${ }^{\mathrm{a}}$ See Appendix A for contact information. 
Miscellaneous

Hand and power tools, pumps, torches, welding equipment, collector glazings, copper sheets, piping and ducting materials, insulation, selective surface material, demonstration equipment, etc.

Grand Total $\$ 21,006.00$ 


\section{APPENDIX G}

EQUIPMENT LIST - NAVARRO COLLEGE 


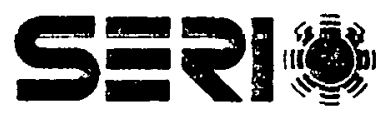


Whereas this equipment provides detailed reference information to specific manufacturers, it is not meant to be an endorsement of the specific product or equipment. The detail is given to provide enough information that similar component considerations can be made and compared. Information on Navarro College's equipment was given to the author by Michael Z. Lowenstein, who was project Director and is now a staff member with SERI.

\section{Closed Loop Domestic Hot Water System}

1 Lennox "Solar Mate" Hot Water System - 3 Collectors (double glazed) including pump, proportional flow controller, expansion tank, storage tank with heat exchanger ( 82 gallon), and tempering valve

1 Similar system except with single glazed collectors $\quad 1,650$

2 Flow meters (approximately $\$ 90$ each) 180

Total for Systems

Complete Solar Systems

Minimum-sized operational liquid and air systems

Air System Equipment

Collectors - 200 square feet (Solaron, $\$ 16.50$ per square foot)

$\$ 3,300$

Insulated Air Ducting - 200 feet $(\$ 3.50$ per foot)

Solar Air Mover, including differential thermostat, blower, and motorized dampers (Solar Control Corp. including 25\% educational discount)

Solarstat Solid State Solar System Monitor (Solar Control Corp. including $25 \%$ educational discount)

Domestic Hot Water Sub-Assembly, including air-water heat exchanger, circulating pump, and storage tank

Energy Storage System, rockbed, 200 cubic feet, $5^{\prime} \times 25^{\prime} \times 8^{\prime}$ high. Constructed on-site. Includes: plywood and lumber, insulation, rock.

Water System Equipment

Collector - 200 Square feet (numerous manufacturers, $\$ 16.50 /$ sq.ft.)

$\$ 3,300$

Insulated Piping - 200 feet at $\$ 2.00$ per foot

Circulating Pumps, 2 (Grundfos Pump UPS20-42-F, \$75.00)

Storage Tank, 600 gallon, low pressure

Solenoid Valves (Skinner 4 at $\$ 45.00$ each)

Differential Controller (Hawthorne Variflow II-1.510) 


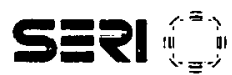

Liquid-Liquid Heat Exchanger, 2 (one for collector loop, one for providing heat load to system $\$ 440.00$ each)

Liquid-Air Heat Exchanger with Blower

Anti-freeze, 10 gallons at $\$ 4.00$ per gallon

Subtotal

Solar Meteorological Data Instrumentation

Solar Tracker, Model ST-1

$\$ 820$

Eppley Normal Incidence Pyrheliometer, with clear glass, Model 650

Eppley Precision Spectral Pyranometer, with clear glass, Model 646

Dual Channel Printout System, with synchronous tempotec timer, Model 618-3DCP

Panel Digital Voltmeter

Recording Thermograph, Model No. 151-1, Science Associates, Inc.

Princeton Wind Set No. 414, Science Associates, Inc.

Subtotal

$\underline{\text { Solar Collector }}$

Used for gaining working experience with different types of collectors.

Forty square feet each of three different liquid collectors at $\$ 15.00$ per square foot

Modular Collector Kits (New Jersey Aluminum, $\$ 660.00$ each)

Changeable Absorber Plates for Modular Collectors, copper roll bond, 2 (Kal wall Corp., $\$ 88.00$ each)

Aluminum Roll Bond, 2 (Kalwall Corp., $\$ 55.00$ each)

Flat Aluminum for Air Systems, 2 (Kalwall Corp., $\$ 30.00$ each)

Circulating Pumps, 2 (Kalwall Corp., Teel pump, \$55.00)

Air Blower, 2 (Kalwall Corp., Dayton $\mathrm{K} 4 \mathrm{CO} 13, \mathbf{2 8 . 0 0 )}$

Miscellaneous Materials, including sealant, tubing, ducting, insulation, etc.

Flowmeters, 2 (Wallace \& Tiernan, Model 5510AO-1-2-06, \$90.00)

Various Glazing Materials, including glass and fiberglass

Three Focusing Tracking Collector Units, with tracking mechanisms

(Northrup, Inc.)

Six Parabolic Nontracking Focusing Units (White Line Corp., $\$ 110$ per unit)

Mounting Materials for all Collectors

Subtotal

$\$ 6,922$ 
iil

\section{Thermal Storage}

Liquid Storage System, including steel and concrete drums, supports and insulation

Air Storage System, including plywood, lumber, insulation rocks, etc.

Latent Heat Storage System, including plywood, insulation, heat storage trays, and fused salts

Subtotal

Instrumentation Support Equipment Special to Solar Technology

Hot Wire Anemometer [Science Associates, Inc. No. 447(1)-1]

Digital Thermometer with External Thermistor Probe, 5

(Electrom etics, \$140 each)

Thermistor Sensors, 30 (Electrometics, $\$ 12$ each)

Thermistor Switch Box (Electrometics)

Thermistor Hook-up Wire, 3,000 feet (Radio Shack, $\$ 0.10$ per foot)

Flowmeters, 3 (Wallace \& Tiernan, Model 5510A0-1-2-06, \$93.00)

Subtotal

\section{Solar System Simulators}

Simulators are extremely useful for teaching principles before the student experiments on the real equipment. This type of simulator is completely interactive, permitting the teacher to familiarize the student with the effect of varying numerous solar parameters. Twenty-four major system malfunctions can be-inserted by the teacher to introduce the student to trouble-shooting.

Solar System simulators (Omnidata, Inc. Model 327)

Printer Drawer Interface (Omnidata, Inc. PDI-1)

Student Tracking Printer (Omnidata, Inc. STP)

Subtotal

\section{Calculators}

Many of the sizing and design calculations are being carried out on small, programmable calculators. There are several companies making available prewritten program cards for solar sizing and design calculations. Calculators of this type are not standard equipment at most colleges. 
sin

Programmable Calculator, 2 (Texas Instruments, Model 59, \$253.00) $\quad$ \% 506

Printer for Calculator, 2 (Texas Instruments, Model

PC-100A, \$176.00)

Programmable Calculator with printer, 2 (Hewlett-Packard, Model 97, \$710.00)

Subtotal

Shipping estimate for above items:

Total Laboratory Costs

In addition, one could spend another $\$ 6,000$ on solar refrigeration equipment and $\$ 2,000$ on photövoitalc equipment. As well, there will be construction costs incurred for installation of outdoor demonstrations. Navarro College has estimated such costs to be around $\$ 8,500$. 
APPENDIX H

SCOTT COMMUNITY COLLEGE

SOLAR ENERGETICS TECHNOLOGY

EQUIPMENT LIST 


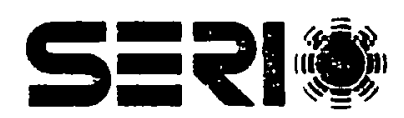


Supplied by Robert N. חlingsworth ${ }^{\mathrm{a}}$

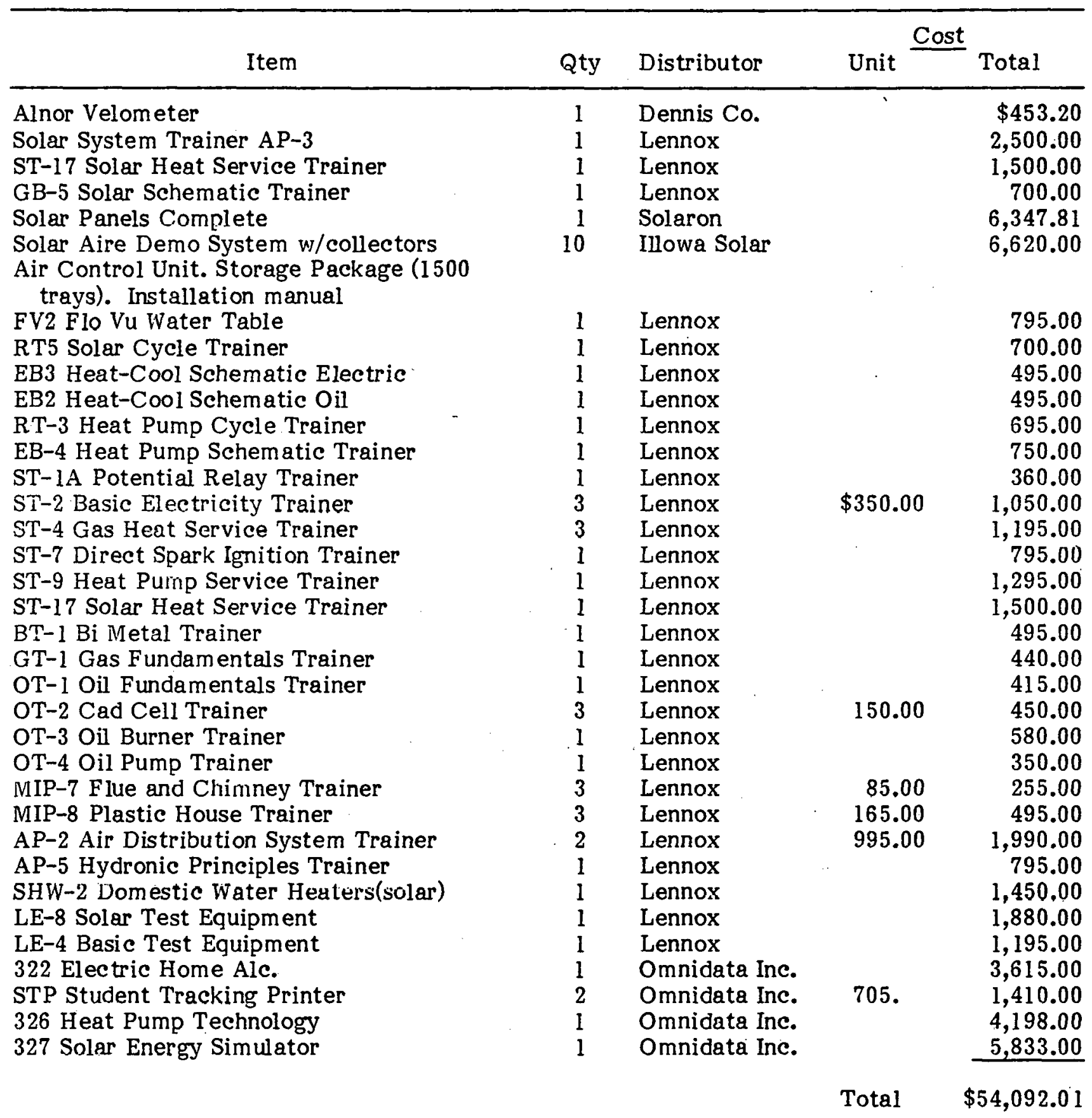

${ }^{a}$ See Appendix A for contact information. 


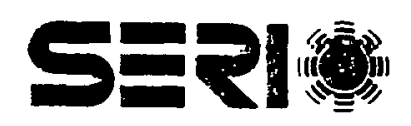




\section{APPENDIX I}

CLASSROOM MATERIALS SAMPLE COMMUNITY COLLEGE OF DENVER RED ROCKS CAMPUS

SOLAR ENERGY INSTALLATION \& MAINTENANCE PROGRAM 


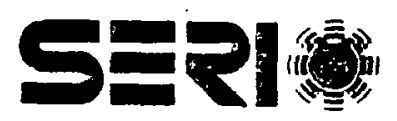


Supplied by Craig Hil ton ${ }^{2}$

\section{BIBLIOGRAPHY}

COURSE: Basic Solar Systems, Solar System Design and Layout, Solar Panel Arrays

Anderson, B.; Riordan, M. 1976. The Solar Home Book: Heating, Cooling, and Designing with the Sun. Harrisville, $\mathrm{NH}$ : Cheshire Books.

COURSE: Domestic Hot Water System, Solar System Maintenance, Solar Panel Installation

Montgomery, Richard 1978. The Solar Decision Book: Your Guide to Making a Sound Investment. Midland, MI: Dow Corning Corp.

Sheet Metal and Air Conditioning Contractors National Association. 1978. Fundamentals of Solar Heating. Vienna, Virginia.

COURSE: Solar Engineering Technology I and II

Winn, B.; Karaki, S.; Lof, G.; et al. 1977a. Solar Heating and Cooling of Residential Buildings: Design of Systems. Ft. Collins, CO: Colorado State University, Solar Energy Applications Laboratory; U.S. GPO; Oct.

- 1977a. Solar Heating and Cooling of Residential Buildings: Sizing, Installation and Operation of Systems. Ft. Collins, CO: Colorado State University, Solar Energy Applications Laboratory; U.S. GPO; Oct.

International Telephone and Telegraph Corp. 1977. Solar Heating Systems Design Manual. Morton Grove, IL: Training \& Education Dept. Fluid Handling Division.

U.S. Dept. of Housing and Urban Development. 1977. Intermediate Minimum Property Standards for Solar Heating and Domestic Hot Water System. U.S. Government Printing Office.

COURSE: Basic Solar Controls, Advance Solar Controls.

Miles, V.C. 1965. Thermostatic Control Principles and Practice. London, England: Butterworth \& Co., 88 Kingways.

Farber, Joseph. 1978. Control and Pumps for Solar Heating and Cooling. Newark, DE: Publishing Office of the American Section of the International Solar Energy Scciety; Dec.

${ }^{a_{S}}$ eee Appendix A for contact information. 


\section{COURSE: Passive Solar System}

Mazria, Edward. 1979. The Passive Solar Energy Book. Emmaus, PA: Rodale Press.

Prowler, Don, ed. 1978. Proceedings of the 1978 Passive Solar Conference, Philadelphia, PA., March 1978. Philadelphia, PA. Mid-Atlantic Solar Energy Assn.

Cook, Jeffrey. Passive Systems '78, Newark, DE: Publishing Office of the American Section of the International Solar Energy Society; Oct. 1976.

Stromberg, R.P.; Woodall, S.O. 1977. Passive Solar Buildings: A Compilation of Data and Results. Springfield, VA: National Technical Information Service; August.

Kroner, Wal ter; Haviland, David. 1978. Passive Design Ideas for the Finergy Conscious Builder. Rockville, MDr A National Solar Ileating and Cúling Information Center Publication.

Students are provided with handout materials in each class. Memberships in the International Solar Energy Society and the Colorado Solar Energy Association are encouraged together with subscriptions to such magazines as Solar Age, Solar Engineering, and Solar Heating \& Cooling.

\section{Code Information Used in Classroom:}

International Association of Plumbing and Mechanical Officials. 1976. Uniform Solar Energy Code, 1976 Edition. Los Angeles, CA; Sept.

International Association of Plumbing and Mechanical Officials. 1977. Uniform Plumbing Code, 1976 Edition. Los Ángeles, CA; Jan.

Sheet Metal and Air Conditioning Contractors National Association. 1978. Installation Standards for One and Two Family Dwellings and Mul tifamily Housing Including Solar. Vienne, VA; Jan.

State of Colorado, Office of State Planning and Budgeting and the Department of Local Affairs. 1977. State of Colorado Energy Conservation Standards. Denver, CO: Colorado Division of Housing; Nov. 